\title{
Investigation of Bartonella henselae and Bartonella clarridgeiae Prevalance in Cats
}

\author{
Şükrü Kırkan*, Uğur Parınn', Hafize Tuğba Yüksel ${ }^{1}$ and Saliha Melda Erinç² \\ ${ }^{1}$ Department of Microbiology, University of Aydin Adnan Menderes, Faculty of Veterinary Medicine, Aydin, Turkey \\ ${ }^{2}$ Department of Microbiology, University of Aydın Adnan Menderes, Institute of Health Sciences, Aydin, Turkey
}

Submission: December 12, 2018; Published: October 23, 2019

*Corresponding author: Şükrü Kırkan, Department of Microbiology, University of Aydın Adnan Menderes, Faculty of Veterinary Medicine, Aydin, Turkey

\begin{abstract}
In this study, 50 blood samples taken from urban and stray cats which were examined in a private veterinary clinic in İzmir province were investigated by PCR method. PCR studies revealed that Bartonella spp. was identified from a total of $\% 12$ of the samples. PCR identification results were $8 \%$ for $B$. hensela and $4 \%$ for B. clarridgeiae for species-based distribution. In conclusion, Bartonella species which have zoonotic importance were detected. Especially, it is confirmed the necessity of the distribution of $B$. henselae which transmit to human from cat fleas and importance of preventive flea medication to pet owners for feedback.
\end{abstract}

Keywords: Bartonella spp; B. henselae; B. clarridgeiae; Cat Scratch Disease; PCR

Abbreviations: PCR: Polymerase Chain Reaction; CSD: Cat Scratch Disease; RFLP: Restriction Fragment Length Polymorphism; BA: bacillary angiomatosis

\section{Introduction}

Bartonella species are common zoonotic pathogens associated with direct contact to animals in the world. They are small, pleomorphic, Gram-negative, weakly stained bacilli or cocobacilli, oxidase and catalase negative microorganisms Chmielewski [1]. The Bartonella species are highly dependent on the haemin and are able to grow in the medium containing blood. They are fastidious and require a long incubation period at $35{ }^{\circ} \mathrm{C}$ in $5-10 \%$ $\mathrm{CO}_{2}$ concentration. They can be isolated from blood more easily following erythrocyte and leukocyte lysis. Since Bartonella species are fastidious microorganisms, standard biochemical methods for identification are not feasible and are not used in species identification, so molecular genetic methods are used for differential diagnosis. In recent years, the development of molecular techniques has conducted to identify many new Bartonella species. Polymerase Chain Reaction (PCR), which gains practical importance with the introduction of biomolecular methods, can directly indicate the nucleic acid of the infectious agent in the case of infectious diseases. At the same time, different genotypes can be identified by restriction fragment length polymorphism (RFLP) analysis of DNA amplified by PCR Anderson \& Neuman [2]. With these methods, more than 22 known species of this bacterium, which is a sub-member of the $\alpha$-Protobacteria branch, have been identified Guptill [3], Jacomo [4].

Of these, there are three important species of pathogens for humans. These include B. bacilliformis, Carrion disease (Oroya fever and verruga peruana); $B$. quintana causes trench fever; $B$. henselae causes neurological syndromes, infectious diseases of immunodeficient and immunosuppressed individuals, cat scratch disease (CSD) in immunocompromised individuals, bacillary angiomatosis and peliosis especially in HIV positive cases Zangwill [5]. Cat fleas (Ctenocephalides felis) are natural vectors of $B$. henselae in cats. Mites, midges, fleas and lices play an important role on the transmission of Bartonella species Anderson \& Neuman [2], Guptill [3], Angelakis [6]. A species of mosquito for B. bacilliformis (Lutzomyia verrucorum); the body lice end (Pediculus humanis corporis) for B. quintana, are identified as vectors Akkaya [7]. It is known that $B$. henselae, $B$. bacilliformis and $B$. quintana are pathogenic for humans for a long time. However, B. clarridgeiae, $B$. elizabethae, B. grahamii have been accepted as pathogens Jacomo [4], Chomel [8].

Seroepidemiological and bacteriological studies suggest that $B$. henselae is widespread throughout the world in cats. Depending on the geographical location and the life conditions of the cats, the seroprevalence varies between 5-80 \%. The prevalence of bacteriemia may be at a very low rate, or even at a rate determined by more than half of the cat population Boulouis [9]. Cats are reservoirs for the transmission of $B$. henselae to humans Chomel [8], Regnery [10], Koehler [11], Maruyama [12]. The transmission of $B$. henselae to humans is generally possible with cat scratching and bite, possibly also indirectly by cat fleas Zangwill [5], Koehler [13]. Cat fleas harbor B. henselae in their intestines and spread infection with their faeces and transmit infection among the pets. Fleas and 
contaminating nails increase the likelihood of infecting humans during biting by placing flea excreta between teeth during rubbing or while licking themselves Mehock [14].

\section{Material and Methods}

\section{Sample Collection}

The whole blood samples were collected from 50 cats. The neck parts of the cats were first shaved and cleaned with alcohol and iodine before sample collection. Approximately $2 \mathrm{~mL}$ of blood taken from the jugular vein of the cat using a vacuum needle was transferred to EDTA tubes. The samples were brought to the Routine Diagnostic Laboratory Adnan Menderes University Faculty of Veterinary Medicine Department of Microbiology under cold chain. The experimental protocol was approved by the Local Animal Ethics Committee of Adnan Menderes University (2014/094).

\section{Bacterioscopy with Giemsa Staining}

The slide froth is prepared as indicated in the scouring preparation procedure. Prepared froth was first fixed in methyl alcohol for 5 minutes. The slides were dyed in a $5 \%$ Giemsa solution for 40 minutes at room temperature. After that, the slide was washed with water and dried. Immersion oil was dropped on the preparations and examined under microscope.

\section{DNA Isolation}

DNA isolation was performed according to the procedure with the genomic DNA extraction kit (Fermentas $($ ). The isolated DNAs were stored in cryo-tubes at $-20^{\circ} \mathrm{C}$ in freezing until PCR step.

\section{PCR}

Master Mix Preparation: PCR amplification for a sample in the PCR reactions for the identification of Bartonella henselae and Bartonella clarridgeiae species in this study was performed by mixture consisting of $5 \mu \mathrm{l}$ PCR Buffer, $5 \mu \mathrm{l}$ from $25 \mathrm{mM} \mathrm{MgCl}, 10$ $\mathrm{mM}$ deoxynucleotide triphosphate (dNTP) $1 \mu \mathrm{l}, 25$ pmol primers which were prepared by $1 \mu \mathrm{l}$ of BARTON- 1 and BARTON-2, $0.5 \mu \mathrm{l}$ of Taq polymerase $(5 \mu \mathrm{l}), 10 \mu \mathrm{l}$ of template DNA and $26.5 \mu \mathrm{l}$ of distilled water $\left(\mathrm{ddH}_{2} \mathrm{O}\right)$ Johnson [15]. Once the mastermix was prepared, $0.2 \mu \mathrm{L}$ of the tubes were added to the mastermix, numbered up to the sample number, and $40 \mu \mathrm{l}$ of which was prepared. Then, $10 \mu \mathrm{l}$ of the extracted template DNA was taken, inserted into the relevant tube, and the mouths tightly closed. The prepared tubes are then loaded into the thermal cycler and programmed. The PCR conditions were initial denaturation at $95^{\circ} \mathrm{C}$ for $5 \mathrm{~min}, 37$ cycles of denaturation at $96^{\circ} \mathrm{C}$ for $20 \mathrm{sec}$, annealing at $55^{\circ} \mathrm{C}$ for $30 \mathrm{sec}$, extension at $72{ }^{\circ} \mathrm{C}$ for $1 \mathrm{~min}$ and final extension at $72{ }^{\circ} \mathrm{C}$ for $3 \mathrm{~min}$.

\section{Gel Electrophoresis}

$10 \mu \mathrm{l}$ of the PCR products were mixed with $3 \mu \mathrm{l}$ of $6 \mathrm{x}$ loading dye solution. The whole mixture was taken, and the $2 \%$ agarose gel was loaded into the appropriate position of the gel. The electrophoresis was run for 15 minutes at $80 \mathrm{~V} 500 \mathrm{~A}$ current and then for 60 minutes at $40 \mathrm{~V} 500 \mathrm{~A}$. The gel was placed in the chamber of the transilluminator device connected to the computer. After visualized under UV light, the fragment lengths were assessed separately for each PCR. The assessment was made as previously reported. In the PCR analysis, fragment length of $588 \mathrm{bp}$ for $B$. henselae and $585 \mathrm{bp}$ for B. clarridgeia were investigated.

\section{Results}

\section{Assessment of the Cats}

In our research, blood samples taken from 50 stray and pet cats were brought to the routine diagnosis laboratory of the Department of Microbiology, Faculty of Veterinary Medicine, Adnan Menderes University. The age range of the cats was between 7 months and 19 years. Twenty-seven (54\%) of the cats were female and $23(46 \%)$ were male. Twenty-seven of (54\%) cats were kept as pets and $23(46 \%)$ of them were stray cats.

\section{Giemsa Staining Results}

Fifty blood samples were examined under microscope after preparation of froths by Giemsa staining method. Intra-erythrocytic blood cells suggesting the presence of Bartonellosis infection was detected in 6 specimens.

\section{PCR Results}

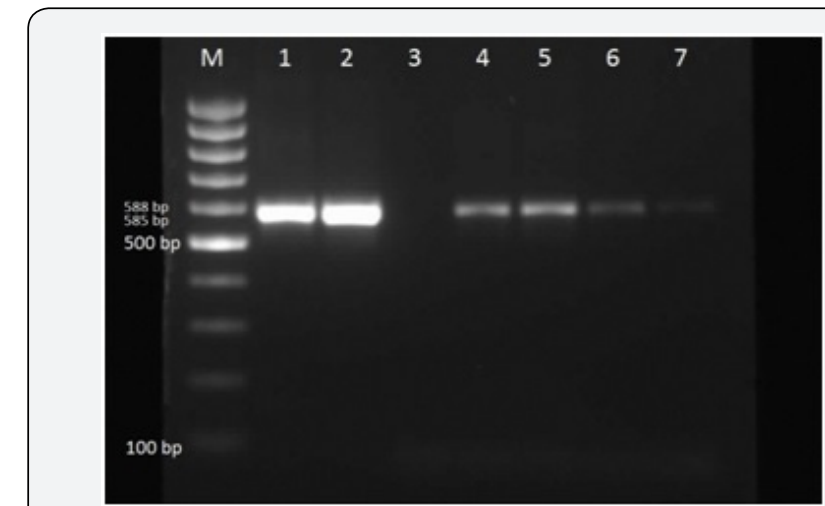

Figure 1: Electrophoresis image obtained by PCR.

M: 1000 bp DNA ladder, 1: B. henselae positive control, 2: B. clarridgeiae positive control, 3: Negative control, 4-5: B. clarridgeiae positive sample, 6-7: B. henselae positive sample.

A total of $6(12 \%)$ samples of Bartonella spp. positivity was obtained after PCR analyses. Four (8\%) of B. henselae and 2 (4\%) of PCR positive specimens were identified as B. Clarridgeiae (Figure 1). The presence of intra-erythrocytic blood cells were also detected in the Giemsa staining of the PCR positive samples in the obtained results, thus further strengthened our research findings. As a result of the PCR run, $12 \%$ of the samples contained Bartonella spp. positivity. As a result of the PCR positivity of 50 samples, the percentage distribution by species was determined as $8 \% B$. henselae and $4 \%$ B. clarridgeiae (Figure 1). Gender-based distributions of Bartonella species in cats with PCR positivity showed that 2 B. henselae and 1 B. clarridgeiae were identified from 27 female cats and 2 B. henselae and 1 B. clarridgeiae were identified from 23 male cats. As a result, it was seen that $7.4 \%$ B. henselae and $3.7 \%$ $B$. clarridgeiae were isolated in female cats. In male cat, $8.6 \%$ of $B$. henselae and $4.3 \%$ of $B$. clarridgeiae were isolated. Two B. hense- 
lae and 1 B. clarridgeiae were identified from 27 pet cats. Two $B$. henselae and 1 B. clarridgeiae were identified from 23 stray cats, 2 B. henselae and 1 B. clarridgeiae. It is seen that $7.4 \%$ B. henselae and $3.7 \%$ B. clarridgeiae were identified from pet cats. $8.6 \%$ of $B$. henselae and $4.3 \%$ of $B$. clarridgeiae were isolated from stray cats. When age-based distributions of PCR-positive Bartonella spp. are examined, it is seen that the age distributions of $B$. henselae in cats are $1,3,5$ and 6 years of age. It is seen that age distribution is 1 and 2 in B. clarridgeiae positive cats.

\section{Discussion}

Cats are considered to be the main reservoir of $B$. henselae and B. clarridgeiae species Anderson \& Neuman [2], Baneth [16]. The seroepidemiological and bacteriological suggest that $B$. henselae is common across the world in cats also. According to geographical localization and lifestyle conditions of the cats, seroprevalence is seen between $5-80 \%$, and the prevalence of bacteriemia varies from the very low rates up to $50 \%$ [9]. Different prevalence rates between studies changes depending on geographical location, population, age, and flea infestation level of the cats Rolain et al. [17]. The main vector that carries B. henselae in cat populations is the fleas. The prevalence of these fleas is the most important factor affecting the seroprevalence and bacteriemia of $B$. henselae in cats. Fleas are significantly affected by climatic characteristics in terms of reproduction and development. The flea infestation is common in temperate and humid climatic regions Jameson et al. [18]. Thus, even regional climate changes within countries cause differences in the prevalence of $B$. henselae seroprevalence and bacteriemia in cats Maruyama [12], Jameson et al. [18]. In a previous study Guptill [19] a 33\% bactericidal rate was found in the United States, $28 \%$ in Northern California, $12 \%$ in Washington and 6\% in Chicago. In other data confirming that $B$. henselae infections differ from cold climates to high temperature and humid climates, $68 \%$ were found in the Philippines despite the presence of $0 \% \mathrm{~B}$. henselae in Norway Boulouis [9].

In another study on the prevalence and seroprevalence of $B$. henselae bacteremia, a $16.5 \%$ seroprevalence of $B$. henselae bacteriemia was reported in pet cats by PCR Gurfield et al. [20], while the prevalence of bacteriemia in stray cats was found as 34\% in another study Heller et al. [21]. Rolain et al. [17], reported $8.1 \% B$. henselae positivity in pet cats. In Italy, Fabbi et al. [22], found that the prevalence of bacteraemia in stray cats was $18 \%$ and seroprevalence was $38 \%$ by PCR and in another study Fabbi et al. [23] the prevalence of bacteriemia was $23 \%$ and seroprevalence was $39 \%$. Cabassi et al. [24] reported a bacterial prevalence of $9.7 \%$. In Spain, Pons et al. [25] reported a bacterial prevalence of 7\%. In addition, Baneth [16] reported the seroprevalence of $39.5 \% B$. henselae in pet cats. The results in other regions of the world using PCR showed that the prevalence of B. henselae was $16.3 \%$ in Thailand Ioue et al. [26] 33.3\% in South Korea Kim et al. [27] 90\% in Brazil Souza [28], 22\% in the Netherlands Bergmans [29] 61\% in the Philippines (61\%) Chomel [30], 17\% in Brazil Staggemeier et al. [31] and $12.7 \%$ in China Yuan [32]
The prevalence of bacteraemia was reported as $8.2 \%$ In Ankara from a study conducted by Celebi et al. [33]. Aydin et al. [34] reported the seroprevalence of $B$. henselae IgG seroprevalence in risk group was found to be $11.5 \%$ in humans (cat/dog owner), $26.47 \%$ for pet dogs, $22.8 \%$ for pet cats, and $52 \%$ for house cats in a total of 281 samples including 131 cats and dogs, 105 cats and 45 dogs. Sigirci [35] reported the prevalence of bacteraemia was $28.1 \%$ in the study conducted by cats in Istanbul region. In this study, the prevalence of bacteraemia was found to be $12 \%$. The reason for the different prevalence value is due to regional climate differences as reported by Celebi [33]. Despite the continental climate in Ankara, the fact that Istanbul has a temperate climate with transition characteristics between the Black Sea climate and the Mediterranean climate and the fact that Izmir is under the influence of the Mediterranean climate are leading to changes in prevalence values. It is therefore expected that these rates will be higher in the cat populations in coastal areas of Turkey, which are under the influence of the Mediterranean climate in our country where urbanization and population density are higher.

There are various methods in the laboratory diagnosis of Bartonella infections. Serological methods have been found to be more practical since the culture and other isolation techniques are time-consuming and difficult to perform, and the weeks are required to obtain results. However, when serological tests are used, it is reported that cross-reactions may occur between Bartonella spp. and other pathogenic bacteria such as C. burnetti and Chlamydophilia spp. Rolain [17], Foucalt [36]. Bergmans [29] reported that identification of Bartonella spp. by culture from cat blood was a more successful way of isolating and identifying DNA by PCR. Heller [27] used culture media and broth (BACTEC medium) to increase the possibility of bacterial isolation. Regnery [10] reported that Bartonella species can be identified only at the genus level due to their negative results with biochemical tests and that species identification should be done with molecular methods. Engvall [37] found that Bartonella spp. after culture in blood from healthy cats in Sweden by the one-step PCR method and isolated B. henselae from 2 of the 91 cats. In this study, Bartonella spp. were detected as $12 \%$ as a result of PCR which was made specifically for BARTON-1 and BARTON-2 primers targeting riboflavin synthase gene.

When the prevalence of bacteraemia was assessed according to lifestyle conditions, it was reported that stray cats were more likely to be bacteriemic than pet cats. The rate of bacteraemia in Berlin was found as $1 \%$ for pet cats and $18.7 \%$ for stray cats Arvand [38]. Gurfield [20] reported that $23.6 \%$ of stray cats and $14.2 \%$ of pet cats were bacteriemic detected in the study conducted in France. Chomel [8] reported 24\% bacteriemia ratio in pet cats and $61 \%$ in stray cats. Childs [39] found the seroprevalence of $B$. henselae as $12 \%$ in pet cats and $44 \%$ in stray cats. Barnes [40] reported that seroprevalence of $B$. henselae was $40.6 \%$ in pet cats and $41.8 \%$ in stray cats, but no significant difference between streets and house cats in terms of positivity. Celebi [33] found that 
the bacteremia rate of cats in Ankara was $10.7 \%$ for pet cats and $2.9 \%$ for stray cats and was not statistically significant. The prevalence of bacteriemia in this study was $6 \%$ in pet cats and $6 \%$ in stray cats and was not found significant.

Higher prevalence was found in the female cats Sander [41] while in some studies it was reported that male cats had a higher prevalence Zangwill [5], Maruyama [12], Bergmans [29]. In Celebi's study [42], $13.8 \%$ of $B$. henselae positivity in female stray cats and $2.7 \%$ B. henselae positivity were observed in the male cats. In the study of bacteremia positivity of female cats was determined as $24.4 \%$ and male cats as $31.4 \%$. In this study, the rate of bacterial infection in female cats was $6 \%$ and the rate of bacteremia in male cats was $6 \%$. The results were not found significant. This study agrees with other studies Fabbi [22], Gurfield et al. [43] since there is no significant difference in the positive rate between the two genders and that gender is not a risk factor associated with bacteremia.

When the prevalence of $B$. henselae, B. clarridgeiae, and $B$. koehlerae is assessed, $B$. henselae is the majority of the Bartonella species isolated from cats. In some cats both $B$. henselae and B. clarridgeiae bacteremia can be seen together Celebi [42]. Forty-eight (83\%) of the 48 Bartonella spp. isolated from the cats in Israel were found to be $B$. henselae, 7 (15\%) were B. clarridgeiae and $1(2 \%)$ were B. koehlerae Boulouis [9]. Of the 19 Bartonella species isolated in the Philippines, 13 (68.4\%) were identified as B. henselae, $2(10.5 \%)$ were B. clarridgeiae and 4 (21\%) were B. henselae and B. clarridgeiae Chomel [30]. Gurfield [43] found that B. henselae and B. clarridgeiae together accounted for $1.1 \%$ of 436 cats, $50 \%$ B. henselae, $21 \%$ B. clarridgeiae, $11 \%$ B. henselae and B. clarridgeiae together. Heller [21] identified 70\% B. henselae and $30 \%$ B. clarridgeiae in 94 cats and Maruyama [44] identified $82.9 \%$ B. henselae, $11.8 \%$ B. clarridgeiae, 5.3\% B. henselae and B. clarridgeiae in 275 cats. Marston [45] reported $43 \%$ B. henselae and $21 \%$ B. clarridgeiae in 54 cats and Celebi [33] identified 77\% B. henselae, and $23 \%$ B. clarridgeiae in 256 cats. In addition, Celebi [33] identified 10 (\% 77) B. henselae and 3 (\% 23) B. clarridgeiae from 102 stray cats, 11 (77\%) of $B$. henselae from pet cats.

Guptil [19] have not found identification of B. clarridgeiae while noted 24\% B. henselae from 231 cats, Chomel [46] identified $22.6 \%$ B. henselae of 93 cats, and Fabbi [22] identified 18\% B. henselae of 769 cats. In the study of Sigirci [35], B. clarridgeiae was not identified while $B$. henselae was isolated from 27 (28.1\%) of 96 cats. In this study, B. henselae was isolated in 4 (8\%) of 50 cases and B. clarridgeiae was isolated in $2(4 \%)$ cases. These results indicate that $B$. clarridgeiae cannot be isolated at high levels of variation and in the frequency of appearance in cat populations, while supporting other studies showing $B$. henselae prevalence. Bartonella species are a common zoonotic pathogen in the world associated with contact with animals Chmielewski [1]. They are small, pleomorphic, gram negative, weakly stained bacilli or cocobacilli, oxidase and catalase negative microorganisms Guptill [3], Jacomo [4].
Due to slow growing period, standard biochemical methods for diagnosis are not suitable and are not used for species discrimination, so molecular genetic methods are used for species identification. Of these, there are three important species of pathogens for humans. These include B. bacilliformis, Carrion disease (Oroya fever and verruga peruana); B. quintana causes trench fires; $B$. henselae causes neurological syndromes Kordick \& Breitcshwerdt [47], infecting humans from natural reservoir catheters to immunodeficient and immunocompetent patients with cat scratch disease (CTS), immunocompromised individuals with bacillary angiomatosis (BA), bacillary peliosis and especially HIV. It is known that $B$. henselae, $B$. bacilliformis and B. quintana are pathogenic for humans for a long time. Recently, however, $B$. clarridgeiae, B. elizabethae, B. grahamii have been accepted as pathogens Jacomo [4], Chomel [48]. In this study, the presence of $B$. henselae and B. clarridgeiae in stray and pet cats visiting the private veterinary clinic determined in İzmir was revealed by PCR after Giemsa staining. As a result, Bartonella species, which are important for the people of existence, have been identified since they carry a zoonotic character in the Izmir region.

\section{Acknowledgements}

This research was granted by Aydın Adnan Menderes University Commission of Scientific Research Projects with grant number VTF-15006.

\section{References}

1. Chmielewski T, Podsiadły E, Tylewska-Wierzbanowska S (2007) Presence of Bartonella spp. in various human populations. Pol J Microbiol 56(1): 33-38.

2. Anderson BE, Neuman MA (1997) Bartonella spp. as emerging human pathogens. Clin Microbiol Rev 10(2): 203-219.

3. Guptill L (2010) Bartonellosis. Vet Microbiol 140(3-4): 347-359.

4. Jacomo V, Kelly PJ, Raoult D (2002) Natural history of Bartonella infections (an exception to Koch's postulate). Clin Diagn Lab Immunol 9(1): 8-18.

5. Zangwill KM, Hamilton DH, Perkins BA (1993) Cat scratch disease in Connecticut: Epidemiology, risk factors, and evaluation of a new diagnostic test. N Engl J Med 329(1): 8-13.

6. Angelakis E, Billeter SA, Chomel BB, Raoult D (2010) Potential for tick borne Bartonelloses. Emerg Infect Dis J 16: 385-391.

7. Akkaya Y (2011) Investigation of antibody seroprevalence against Bartonella bacilliformis in adults working in occupational groups at risk in rural areas, MS thesis, Pamukkale Univ, Denizli, Turkey.

8. Chomel BB, Abbott RC, Kasten RW, Floyd-Hawkins KA, Kass P, et al. (1995) Bartonella henselae prevalence in domestic cats in California: risk factors and association between bacteremia and antibody titers. J Clin Microbiol 33(9): 445-2450.

9. Boulouis HJ, Chang CC, Henn JB (2005) Factors associated with the rapid emergence of zoonotic Bartonella infections. Vet Res 36(3): 383-410.

10. Regnery RL, Anderson BE, Clarridge JE, Barradas MCR, Jones DC, et al. (1992) Characterization of a novel Rochalimaea species, $R$. henselae $s p$. nov, isolated from blood of a febrile, human immunodeficiency virus-positive patient. J Clin Microbiol 30(2): 265-274. 
11. Koehler JE, Glaser CA, Tappero JW (1994) Rochalimaea henselae infection a new zoonosis with the domestic cat as reservoir. JAMA 271(7): 531-535.

12. Maruyama S, Nogami S, Inoue I, Namba S (1996) Isolation of Bartonella henselae from Domestic Cats in Japan. J Vet Med Sci 58(1): 81-83.

13. Koehler JE, Sanchez MA, Garrido CS, Whitfeld MJ, Chen FM, et al. (1997) Molecular epidemiology of Bartonella infections in patients with bacillary angiomatosis-peliosis. N Engl J Med 337(26): 1876-1883.

14. Mehock JR, Greene CE, Gherardini FC, Hahn TW, Krause DC (1998) Bar tonella henselae invasion of feline erythrocytes in vitro. Infect. Immun 66(7): 3462-3466.

15. Johnson G, Ayers M, McClure SC, Richardson SE, Tellier R (2003) Detection and identification of Bartonella species pathogenic for humans by PCR amplification targeting the riboflavin synthase gene (ribC). J Clin Microbiol 41(3): 1069-1072.

16. Baneth G, Kordick DL, Hegarty BC, Breitschwerdt EB (1996) Comparative seroreactivity to Bartonella henselae and Bartonella quintana among cats from Israel and North Carolina. Vet Microbiol 50(1-2): 95103.

17. Rolain JM, Brouqui P, Koehler JE, Maguina C, Dolan MJ, et al. (2004) Recommendations for treatment of human infections caused by Bartonella species. Antimicrob. Agents Chemother 48(6): 1921-1933.

18. Jameson P, Greene C, Regnery R, Dryden M, Marks A, et al. (1995) Prevalence of Bartonella henselae antibodies in pet cats throughout regions of North America. J Infect Dis 172(4): 1145-1149.

19. Guptill L, Wu CC, Hogenesch H, Slater LN, Glickman N, et al. (2004) Prevalance, risk factors, and genetic diversity of Bartonella henselae infections in pet cats in four regions of the United States. J Clin Microbiol 42(2): 652-659.

20. Gurfield AN, Boulouis HJ, Chomel BB, Heller R, Kasten RW, et al. (1997) Coinfection with Bartonella clarridgeiae and Bartonella henselae and with different Bartonella henselae strains in domestic cats. J Clin Microbiol 35(8): 2120-2123.

21. Heller R, Artois M, Xemar V, De Briel D, Gehin H, et al. (1997) Prevalence of Bartonella henselae and Bartonella clarridgeiae in stray cats. J Clin Microbiol 35(6): 1327-1331.

22. Fabbi M, DeGiuli L, Tranquillo M, Bragoni R, Casiraghi M et al. (2004a) Prevalence of Bartonella henselae in Italian stray cats: evaluation of serology to assess the risk of transmission of Bartonella to humans. J Clin Microbiol 42(1): 264-268.

23. Fabbi M, Vicari N, Tranquillo M, Pozzi C, Prati P, et al. (2004) Prevalence of Bartonella henselae in stray and domestic cats in different Italian areas: evaluation of the potential risk of transmission of Bartonella to human. Parassitologia 46(1-2): 127-129.

24. Cabassi CS, Farnetti E, Casali B, Taddei S, Donofrio G, et al. (2002) Isolation of Bartonella henselae from domestic cats in an Italian urban area. New Microbiol 25(2): 253-257.

25. Pons I, Sanfeliu I, Quesada M, Anton E, Sampere M, et al. (2005) Prevalence of Bartonella henselae in cats in Catalonia, Spain. Am J Trop Med Hyg 72(4): 453-457.

26. Inoue K, Maruyama S, Kabeya H, Kawanami K, Yanai K, et al. (2009) Prevalence of Bartonella infection in cats and dogs in a metropolitan area, Thailand. Epidemiol Infect 137(11): 1568-1573.

27. Kim YS, Seo KW, Lee JH, Choi EW, Lee HW, et al. (2009) Prevalence of Bartonella henselae and Bartonella clarridgeiae in cats and dogs in Korea. J Vet Sci 10(1): 85-87.

28. Souza AM (2009) Freqüencia de infecçao por Bartonella spp. e alteraçoes sangüineas em gatos domesticos no estado do Rio de Janerio-Brasil, PhD thesis, Federal Fluminense Univ, Rio de Janerio, Brasil.
29. Bergmans AM, De Jong CMA, Van Amerongen, G, Schot CS, Schouls LM (1997) Prevalence of Bartonella species in domestic cats in the Netherlands. J Clin Microbiol 35(9): 2256-2261.

30. Chomel BB, Carlos ET, Kasten RW, Yamamoto K, Chang CC, et al. (1999) Bartonella henselae and Bartonella clarridgeiae infection in domestic cats from The Philippines. Am J Trop Med Hyg 60(4): 593-597.

31. Staggemeier R, Venker CA, Klein DH, Petry M, Spilki FR, et al. (2010) Prevalence of Bartonella henselae and Bartonella clarridgeiae in cats in the south of Brazil: a molecular study. Mem. Inst. Oswaldo Cruz 105(7): 873-878.

32. Yuan C, Zhu C, Wu Y, Pan X, Hua X (2011) Bacteriological and Molecular Identification of Bartonella Species in Cats from Different Regions of China. PLOS Negl Trop Dis 5(9): 1301.

33. Celebi B, Kılıç S, Aydın N, Tarhan G, Carhan A, et al. (2009) Investigation of Bartonella henselae in cats of Ankara, Turkey. Zoonoses Public Health 56(4): 169-175.

34. Aydin N, Gultekin B, Kurkan S, Aksoy M, Telli M, et al. (2011) Seroprevalence of serum antibodies against Bartonella henselae in human population and domestic cats and dogs. In the Proceedings of $11^{\text {th }}$ General meeting American Society for Microbiology.

35. Sigirci B (2009) Investigation of Bartonella henselae with bacteriologic and polymerase chain reaction technique in the cats of Istanbul region, $\mathrm{PhD}$ thesis. Istanbul Univ., Istanbul, Turkey.

36. Foucalt C, Rolain JM, Raoult D, Brouqui P (2004) Detection Bartonella quintana by direct immunflouresence examination of blood smears of a patient with trench fever. J Clin Microbiol 42(10): 4904-4906.

37. Engvall EO, Fasth C, Brändström B, Fermér C, Blomqvist G, et al. (2003) Prevalence of Bartonella henselae in young, healthy cats in Sweden. Vet Res 152(12): 366-369.

38. Arvand M, Klose AJ, Schwartz-Porsche D, Hahn H, Wendt C (2001) Genetic variability and prevalence of Bartonella henselae in cats in Berlin, Germany and analysis of its genetic relatedness to a strain from Berlin that is pathogenic for humans. J Clin Microbiol 39(2): 743-746.

39. Childs JE, Rooney JA, Cooper JL, Olsen JG, Regnery RL (1994) Epidemiologic observations on infection with Rochalimaea species among cats living in Baltimore. J Am Vet Med Assoc 204(11): 1775-1778.

40. Barnes A, Bell SC, Isherwoods DR, Bennets M, Carter SD (2000) Evidence of Bartonella henselae infection in cats and dogs in the United Kingdom. Vet Rec 147: 673-677.

41. Sander A, Bühler C, Pelz K, Cramm Ev, Bredt W (1997) Detection and identification of two Bartonella henselae variants in domestic cats in Germany. J Clin Microbiol 35(3): 584-587.

42. Celebi B (2007) Seroprevalence of Bartonella henselae and determination of isolates by PCR in cats of Ankara region, PhD thesis. Ankara Univ, Ankara, Turkey.

43. Gurfield AN, Boulouis HJ, Chomel BB, Kasten RW, Heller R, et al. (2001) Epidemiology of Bartonella infection in domestic cats in France. Vet Microbiol 80(2): 185-198.

44. Maruyama S, Sakai T, Morita Y, Tanaka S, Kabeya H, et al. (2001) Prevalence of Bartonella species and 16S rRNA Gene Types of Bartonella henselae from Domestic Cats in Thailand. Am J Trop Med Hyg 65(6): 783-787.

45. Marston EL, Finkel B, Regnery, RL, Winoto IL, Graham RR, et al. (1999) Prevalence of Bartonella henselae and Bartonella clarridgeiae in an Urban Indonesian cat population. Clin Diagn Lab Immunol 6(1): 41-44.

46. Chomel BB, Boulouis HJ, Petersen H, Kasten RW, Yamamoto K, et al. (2002) Prevalence of Bartonella infection in domestic cats in Denmark. Vet Res 33(2): 205-213. 
47. Kordick DL, Breitcshwerdt EB (1995) Intraerythrocytic presence of Bartonella henselae. J Clin Microbiol 33(6): 1655-1656.

This work is licensed under Creative Commons Attribution 4.0 License

DOI:10.19080/ARR.2019.05.555661
48. Chomel BB, Kasten RW (2010) Bartonellosis, an increasingly recognized zoonozis. J App Microbiol 10: 1-8.

\section{Your next submission with Juniper Publishers} will reach you the below assets

- Quality Editorial service

- Swift Peer Review

- Reprints availability

- E-prints Service

- Manuscript Podcast for convenient understanding

- Global attainment for your research

- Manuscript accessibility in different formats ( Pdf, E-pub, Full Text, Audio)

- Unceasing customer service

Track the below URL for one-step submission https://juniperpublishers.com/online-submission.php 